\title{
Changing Gender Relations in Media as Social Development
}

By Kafle, Kapil

(Mr. Kafle is a journalist working as an editor for daily newspapers and television in Nepal, Contact: patrakarita_khoj@gmail.com)

\begin{abstract}
The study explores the changing gender relations in media as social development. Changing Gender Relations have been found expressed in the media that can be proven with different examples but the activists and campaigners of gender equality movement are found glued with the decade old metaphors till date. Though the biological identity of a person still determines the power but the gap has been narrowed down. Even men, as activists, have involved advocating for their gender based grievances created as a result of the patriarchy and masculinity. There is discrimination against women, and even violence against them is in the higher volume in the society, but the cases of the remedies have also increased. Power relations have been found very much gendered and sexist, but the account of changes has not been highlighted properly. Changes in power relations are seen in the media but recognition of the same is not made officially. A concept, that most of the women are victims because of their femininity and men are perpetrators because of their masculinity, has also been repeatedly expressed whereas it has been proved that masculinity does not have a biological basis. Methodologically the study is completely based on secondary information of literature review. In conclusion, a concept of social development lies in gender equality has been internalized at least preliminary level by the media that is needed to recognize by the society so that media will be more encouraged to make contributions for the issues of social development.
\end{abstract}

Key words: Gender, Media, Power relation, Social Development,

\section{Introduction}

Generally, relationships between men and women are various types in a society. Mother and son, sister and brother, daughter and father, wife and husband and in-law connections are the social relations of our society based on sex. But, this relationship is not enough to define the dynamism of the relationship made based on sex. Power relationship is dominating to define the relations for the different aspects of the gender connections. As globe is patriarchal till date, social and normative values of the relationship are influenced by the power. Gender relation is power relation between men and women. 
According to Karki (2018), assistant secretary of Ministry of Women, Children and Senior Citizen, as per the social relationship of husband and wife, couple is seemed to be in the same pace but as the economic, cultural and legal power are considered, hypocrisy and the double standard overcome. According to her, society has formed the discriminatory values against women, and we are just following the same rather than challenging the judgments. Most of the media are examples of it but some of them have shown the evidences of the society that has challenged the power relations based in sex.

\section{Objectives and Methodology}

The study explores the changing gender relations in media as social development. Changing Gender Relations have been found expressed in the media that can be proven with different examples but the activists and campaigners of gender equality movement are found glued with the decade old metaphors till date. A concept, that most of the women are victims because of their femininity and men are perpetrators because of their masculinity, has also been repeatedly expressed whereas it has been proved that masculinity does not have a biological basis. Methodologically the study is completely based on secondary information of literature review

\section{Discussions}

\section{Dynamics of Gender Relationship}

Relationships of power between genders can exist in different modes of production (Knopp \& Lauria, 1987). They define that relationships will be different in various contexts. Some of them are culture of the society, patriarchy, masculinity, political system of the state and the legal provisions of the country. Gender relationship with power connection is seemed from womb to the tomb, and seemed to prevail in almost every aspect of the lives of men and women in our society. It prevails even in the beds or sexual relations of the people.

Relations between men and women in the bed have been provided wider and higher values in the society (Karki, 2018). Not only men, even the women have been prioritizing the relations of bed more than it deserves, she writes, there are diversified relationships between husbands and women rather than sexual kind. A husband, who is not active in the bed as per the expectations of the wife, has to encounter serious problems in the family. He falls into the danger zone of the relationship, and is compelled to hear different reservations and doubts from the wife.

Even the legal provisions have been practiced to ask the question if they share a same bed in case of court-sue raised for the divorce between husband and wife. Spouse can't claim of 
physical distance in case proven sharing same bed, according to the legal provisions. Karki (2018) expresses her displeasure on the provisions and practices of the priorities for the sexual relationship.

Women who make the logic of depriving their rights in the absence of husband in the bed is worthless, Karki (2018) describes it as stereotype mentality of the women that upkeeps them subordinated. According to her, there are two reasons for the ill logic in depriving the rights in this case - prioritizing relationship of bed means minimizing several other relations, and sexuality is based on love and situations rather than demands. In spite of it, if a woman thinks that her husband gets more sexual satisfaction with someone other than herself- either she can search for another one for her too or keep quite with the realizations of her weaknesses in the bed (Karki, 2018). As a wife creates an environment of superiority for her husband, he enjoys it and, goes to the bed as taken for granted, and with the feeling of generosity and kindness towards her. In this way, even in the bed, power relation is created, and husband relishes sexual pleasure with power whereas wife gets less or no pleasure even in the bed.

\section{Media}

Gender is the roles given to an individual as per his/her sex by the society. As media is also a part of the society with the powerful impression and influences, it can play the vital role in the business of allocating tasks to the people. Various feminist media studies have concluded that the media have become a part of the problem rather than the solution (Koirala, 2018), but they must listen the voice of the audience for their prosperity and sustainability.

News is a cultural product that reflects dominant cultural assumptions about who and what is important, determined by gender, class and race (Koirala, 2018:3). Nepali media have been found most often giving special priority to the power and authority rather than vulnerable, marginalized and voiceless ones. Prime ministers, ministers, political party leaders, and powerful business persons have been covered as main and prime time news stories whereas general people are found either erased or placed in inside pages of the newspapers and secondary time in the broadcast media.

Masculinity keeps making circle to the power and authority. As it is considered by the society that men are powerful and women are powerless. Women can be considered 'inferior' only if men are considered 'superior'. Women can be and are subordinate only if men are willing and enabled to subordinate them (Bhasin, 2014). Rather than raising the wrong concept and practices of considering women as submissive, media support it just ignoring women and girls, and following 
the men and boys praising their power and stereotype gender relationship. However, there are hundreds of issues to be raised by the media in order to end the gender based violence and sexist discriminations.

Gender discriminations and masculine culture are not favorable even for men and boys. Boys are not permitted even to cry and share the feelings according to the masculine culture. Boys are discouraged for being emotional, gentle and caring or from admitting to being weak or fearful (Bhasin, 2014). Men and boys are forcefully pushed into the role of bread winners, protectors, warriors and fearless person by the society, but media generally don't see the news stories around these issues.

Liberal feminist media theory has not been followed by the Nepali media with full respects. Within this theory, equality and equity are taken as crucial variables in order to support the feminism. Women news sources should be represented in traditionally masculine roles like the military or politicians, when possible and relevant (Koirala, 2018). Though, Nepal has got women army personnel, Nepal Police and Nepal Armed Force, and the politicians holding the legislatives with the rough ratio of 33 percent, but the space of the newspapers have not been found to have occupied more than 14 percent till 2018. Nepali media is not the only one to ignore pleads of liberal feminist media theory and post-colonial media theory, but the international media also follow the same pattern. There is a growing awareness of the limitations and parochialism of theory so steeped in Euro-centrism that it either ignores completely or oversimplifies the complexity of the 'rest' of the world (Hegde, 2010).

\section{Power Relations in Nepal}

On the issues of struggle for power in the references of gender roles, women have been dominating the campaign however some men and boys are also engaged in them. Modern history of the feminist movement starts with Yogmaya Neupane. Though the little source of information, Yogmaya, based in Bhojpur district has been considered as a first woman who raised the voice for gender equality or power relations in an organized manner in Nepal (The KathmanduPost, 2011). On July 14, 1941, when age between 73 to 81, she threw herself into the Arun River in order to pressurize the authority for the equal rights of women as the men. Sixty-seven of her disciples followed suit. According to Prof. Michael Hutt, who presented an outline of Yogmaya's biography in 2011 in Kathmandu, Yogmaya was born between 1860 and 1868 in Simle, Bhojpur. Between 1903 and 1916, Yogmaya renounced the institution of marriage, traveled to holy places and returned to her home district to lead the life of an ascetic. For the rest of her life, she was a permanent resident of Majuwabesi, Bhojpur, where she set up an ashram and observed extreme 
austerity (The Kathmandu Post, 2011). Prof. Hutt is quoted as she sent petitions to Bir Shumsher, Chandra Shumsher and Juddha Shumsher demanding alms and dharma-rajya. Seventy years after the mass sacrifice, Yogmaya's statue was unveiled in Bhojpur on March 8, 2011, to mark the International Women's Day. Feminists owned her as the first among them in the country.

Women's organizations and movement began since 1947 (in Nepal) with the establishment of women's organizations, namely Mahila Samiti (Women's Committee) led by Mrs. Dibya Koirala in 1947, Adarsh Mahila Samiti (Ideal Women's Committee) led by Mrs. Rewanta Kumari Acharya in 1947, Nepal Mahila Sangh (Nepal Women's Association) led by Mrs. Mangala Devi Singh, and Akhil Nepal Mahila Sangathan (All Nepal Women's Organization) led by Mrs. Punya Prabha Devi Dhungana in 1950, Akhil Nepal Mahila Sangh (All Nepal Women's Organization) by Mrs. Kamachaya Devi in 1951, and Mahila Swyam Sewa (Women's Voluntary Services) led by a royal family member in 1952 (Mittra \& Kumar, 2004). All these women activists and leaders were honored as the first generation in the women's movement in Nepal.

There are some arguments about the first organization established by women, however the formal women organization, Nepal Women Association (NWA), was established in 1948 (Koirala, 2018). It mainly functioned in raising political awareness among women. NWA was formed by the women's group as a sister organization of Nepali Congress, a leading political party at that time. Ms. Mangala Devi Singh, political leader and wife of veteran leader Ganesh Man Singh, popularly known as the Iron-Man; was the founder president of NWA.

As by the year of 2015, constitution has adopted the gender equality concept, for this achievement, feminist women and men were revered for their half century long contributions. First time in the history of Nepal in 1990, government decided to give the space for women in the political leadership. According to the Constitution of Nepali Kingdom, all political parties must have at least 5 percent female candidates in the election to the House of Representatives, the Lower House, and at least three women in the Upper House (Asian Development Bank, 1999).

Political changes of 1990 made by first popular movement and Beijing Conference on the issues of CEDAW made foundation of new awareness in Nepali media in the respect of covering the feminists' concerns. Women's representation, their movements, issues and progress in media portrayals have been discussed differently in different contexts. Such discourses were important to recognize feminism in media that was initiated since 1990s (Gurung, 2016 quotes Gallaher, 2014). Beijing Platform for Action at the fourth United Nations World Conference on Women in 1995 acknowledged the media as one of the twelve critical areas of concern. This was a 
breakthrough for gender equality in media.

Improvement in Gender/Power Relationship - Social Development

There was the era where women were restricted even for speaking with the men other than husband, brother and son. They were not permitted to vote for the candidates, and enjoy the political, social and cultural rights. Entertainment was only for the men years ago. Mainly, eastern culture restricted girls and women even for laughing. Bhanubhakta Acharya, Early Poet of Nepal has written Hansnu hunna kadapi nariharule hasneharu besya hun (women are not supposed to laugh, those who laugh are prostitutes) (Bhatta, 2014:10). In his book titled Badhu Shiksha (Lesson to Bride) he writes further, in case of laughing women are not prostitutes, they destroy their houses. He suggests bride to wake up early in the morning before husband and bow head on the feet of husband, speak always in a soft voice, take meal after feeding all the family members, don't be jealous with the other wife of husband, give a full body massage to husband just before sleeping with him and brief all the role she played in last 24 hours.

Banubhakta's time was 1814-1868 B.S. Even widows were pressurized to burn themselves with their demised husbands in the pyre of woods at that time. The scenario has changed over the time but roles of the women and men have been defined by the society even today discriminately.

It may be argued that sex is fixed and based on nature, whereas gender is fluid and based on culture (Koirala, 2018). Society is active almost everywhere to allocate the roles of the male, female and transgender and intersexual people on the basis of their sexuality. Even the media sectors of Nepal are bias to give the role to men and women in the publishing houses (Sancharika Samuh, 2015). Women reporters are prioritized for the soft stories like fashions, ornaments, issues of women's concerns whereas men selected for hard stories like politics, corruptions, issues of national debates and so on. There is another dimension of assignments of the line-officers and willingness of the reporters to the certain beat of the reporting. In 2014, according to the finding of study made by Koirala (2018:122), distribution of news genre by gender was 8 and 92 percent in hard news, 20 and 80 percent in feature and 17 and 83 percent in profile for women and men respectively.

\section{Sources of Gender/Power Relations}

Writers are found producing more analytical write-ups whereas activists are more critical on the issues of power/gender relationship. As activists, we are concerned about the injustice, inequality, marginalization, exclusion, discrimination, stigma, and violence that we see around us (Batliwala, 
2019). She raises the question further, but do we always recognize that power is at the heart of each of these, and at the heart of every social problem? Do we realize that injustice and inequality of every kind is actually an expression of power or a symptom of power structures? She answered herself as; the fact is that power lies at the heart of human relationships and of how societies are organized. So when activists try to change people's lives, or tackle the injustices they face, we are actually trying to change power equations.

'All about power', a book written by Srilatha Batliwala has been published by CREA, a feminist human rights organization based in New Delhi, India in 2019. According to her, power is about not only control but capacities, and that while a power structure is based partly on the control of resources, resources don't entirely explain why power differences continue even when we redistribute resources (Batliwala, 2019). Feminist scholars and activists took a big step forward when they realized that social power is not acting only in the larger world, but within our households and in our most intimate, personal relationships (Batliwala, 2019). She concludes that power is not only one-way force, and as a form of control over other people, and capacity to control the actions and opportunities of others. Who controls over the resources, who owned the land, or have more money were believed to be powerful, she writes, but over time, we have come to understand that power is more complicated than that. In fact, as societies have evolved and changed, so has social power. She has a justification that power comes from the ideology rather than the property and resources.

The ideology of patriarchy, that says men are superior to women, that God has decided this (Adam came first, then Eve), or nature (men are bigger and stronger), or biological roles (women give birth to and have to look after children) or evolution have made it this way. In a patriarchal power structure, your job is to do your gendered duty and not question the overall structure or the injustices you face within it (Batliwala, 2019). Similarly, the concept of race and cast is also examples of it. White is superior than black, Brahmin is higher than other castes is the concept that makes the society divided into powerful and powerless. We are being ideologically trained from our earliest childhood, from before we can question or challenge these ideas, and so we internalize them without conscious awareness, Batliwala writes further, ideology is the most powerful tool created to protect a power structure, because it is the mechanism through which everyone is convinced to participate in that oppressive system, rather than toppling it - they are taught to accept their place in society. According to her, sources of the power are ideology as a first pillar, every day practices or creation of social norms and rules is second pillar, set of institution or social and economic power structure is third and final one is state. 
As much features of changing scenarios of the gender relationship have been covered by the media, it is not enough to represent all the aspects. Though the practices of patriarchy and masculinity are curtailing the rights of women and men till the date, but a substantial number of the people have got the knowledge of discriminations on the basis of sex, caste, race and any other background regardless any sex. Though one of the school of thoughts, however traditional one, claims that men are built as perpetrator to the women but started to realize that men are not permitted even to cry, express the emotions, and pressurized to bear the burdens. All these facts have not only begun to realize but also found substantial number of people campaigning for the gender equality and discrimination free society at least on the basis of sex and other identities.

Social values and metaphors related to sex and gender must be revised in the expression while dealing with the issues of gender equality. This can be done by the mass media in a most effective manner. Media is considered as one of the powerful estates to explore the real pictures of the society, and break the stereotypical pattern of masculinity and patriarchy. Print media like newspapers, electronic media like television and radio and digital media like online news-portal, websites, and social media are really powerful to produce the real picture of the society focusing to the gender/power relationship. Similarly, other means of mass media like books and journals are equally powerful to produce the objectivity and evidences before the public at large.

\section{Conclusion}

Mainstream media of Nepal has started to address the issues of gender equality and social inclusions though found little to meet the need and expectations. Media is considered as one of the powerful estates to explore the real pictures of the society, and break the stereotypical pattern of masculinity and patriarchy. Print media like newspapers, electronic media like television and radio and digital media like online news-portal, websites, and social media are really powerful to produce the real picture of the society focusing to the gender/power relationship. A concept of social development lies in gender equality has been internalized at least preliminary level by the media that is needed to recognize by the society so that media will be more encouraged to make contributions for the issues of social development. 


\section{References}

Asian Development Bank. (1999). Women in Nepal. Kathmandu: https://www.adb.org/sites/ default/files/institutional-document/32561/women-nepal.pdf.

Batliwala, S. (2019). All about Power. New Delhi: CREA.

Bhasin, K. (2014). Exploring Masculinity. New Delhi: Women Unlimited, 7/10, First Floor, Sarvapriya Vihar, New Delhi-110016.

Chamberlain, S. (2011). "Whispers on the wind": social inclusion and the media. Retrieved from https://core.ac.uk/download/pdf/143877478.pdf

Gurung, L. (2016, December). Portrayal Of Women In Print Media: A Nepalese Context. Journal of Educational Thoughts, https://www.researchgate.net/publication/325259566_ Portrayal_of_women_in_print_media_A_Nepalese_Context. Retrieved from https:// www.researchgate.net/publication/325259566_Portrayal_of_women_in_print_ media_A_Nepalese_Context

Hegde, R. S. (2010). Post colonial approaches to communication: Charting the terrain, Engaging the intersections. New York: Routledge.

Hopkins, A. E. (2015). Effects of the 'Spiral of Silence' in Digital Media. Retrieved from http:// www.inquiriesjournal.com/articles/1104/effects-of-the-spiral-of-silence-in-digitalmedia

Karki, R. D. (2018, February). Relationship of Bed. Blue Sky, pp. Year 6, Volume 5.

Knopp, \& Lauria. (1987). Debates and Reports. Retrieved from Gender Relations as a Particular Form of Social Relations: https://www.eswnonline.org/wp-content/uploads/gravity forms/23-b28d66b6400f67d9648a049f8faf44e0/2015/06/Knopp1987-Gender-relations. pdf

Koirala, S. (2018). Gender representation in the Nepali press during pre-conflict, conflict and post-conflict period. Oslo: University of Oslo.

Magar, U. (2017). FNJ's initiation for organizational reformation and purification. In B. K. Joshi, Nepali Journalism: Challenges and Achievements (p. 19). Kathmandu: Federation of Nepali Journalist. 
Mittra, \& Kumar. (2004). (Eds.) Encyclopaedia of Women in South Asia. Delhi: Kalpaz Publications.

My Republica. (2011, May 4). My Republica. Nepal: Yogmaya Neupane: Nepal's First Female Revolutionary.

Sancharika Samuh. (2015). Status of Women Journalists in Nepal. Kathmandu: http://sancharika. org/portal/index.php?p1=content\&p2=165\#.XINgvSgzbIU.

The KathmanduPost. (2011, May 2). Yogmaya, who gave her life fighting Rana atrocities. The Kathmandu. 